1986;292:25-26.

52. Moore EP, Williams EW. Hospital transmission of multiply antibioticresistant Streptococcus pneumoniae. J Infect 1988;16:199-200.

53. Gould FK, Magee JG, Ingham HR A hospital outbreak of antibioticresistant Streptococcus pneumoniae. J Infect 1987;15:77-79.

54. Mercat A, Nguyen J, Dautzenberg B. An outbreak of pneumococcal pneumonia in two men's shelters. Chest 1991;99:147-151.

55. Kim PE, Musher DM, Glezen WP, Rodriguez-Barradas MC, Nahm WK Wright CE. Association of invasive pneumococcal disease with season, atmospheric conditions, air pollution, and the isolation of respiratory viruses. Clin Infect Dis 1996;22:100-106.

56. Tuomanen EI, Austrian R, Masure HR. Pathogenesis of pneumococcal infection. N Engl J Med 1995;332:1280-1284.

57. Loeb M, McGeer A, McArthur M, Walter S, Simor AE. Risk factors for pneumonia and other lower respiratory tract infections in elderly residents of long-term care facilities. Arch Intern Med 1999;159:2058-2064.

58. Orr PH, Peeling RW, Fast M, Brunka J, Duckworth H, Harding GK, et al. Serological study of responses to selected pathogens causing respiratory tract infection in the institutionalized elderly. Clin Infect Dis 1996;23:1240-1245.

59. Marston BJ, Plouffe JF, File TM Jr, Hackman BA, Salstrom SJ, Lipman $\mathrm{HB}$, et al. Incidence of community-acquired pneumonia requiring hospitalization. Results of a population-based active surveillance study in Ohio. The Community-Based Pneumonia Incidence Study Group. Arch Intern Med 1997;157:1709-1718.

60. Troy CJ, Peeling RW, Ellis AG, Hockin JC, Bennett DA, Murphy MR, et al. Chlamydia pneumoniae as a new source of infectious outbreaks in nursing homes. JAMA 1997;277:1214-1218.

61. Kauppinen MT, Herva E, Kujala P, Leinonen M, Saikku P, Syrjala H. The etiology of community-acquired pneumonia among hospitalized patients during a Chlamydia pneumoniae epidemic in Finland. I Infect Dis 1995; $172: 1330-1335$

62. Grayston JT. Infections caused by Chlamydia pneumoniae strain TWAR. Clin Infect Dis 1992;15:757-761.

63. Kauppinen M, Saikka P. Pneumonia due to Chlamydia pneumoniae: prevalence, clinical features, diagnosis, and treatment. Clin Infect Dis 1995;21(suppl 3):S244-S252.

64. Centers for Disease Control and Prevention. Pneumococcal and influenza vaccination levels among adults aged $\geqslant 65$ years-United States, 1995. MMWR 1997;46:913-919.

65. Centers for Disease Control and Prevention. Influenza and pneumococcal vaccination levels among adults aged $\geqslant 65$ years-United States, 1997. MMWR 1998;47:797-802.

66. Musher D, Groover JE, Graviss EA, Baughn RE. The lack of association between aging and postvaccination levels of IgG antibody to capsular polysaccharides of Streptococcus pneumoniae. Clin Infect Dis 1995;22:165-167.

67. Hedlund JU, Kalin ME, Ortqvist AB, Henrichsen J. Antibody response to pneumococcal vaccine in middle-aged and elderly patients recently treated for pneumonia. Arch Intern Med 1994;154:1961-1965.

68. Buikema AR, Singleton JA, Sneller VP, Strikas RA. Influenza and pneumococcal vaccination in nursing homes, US, 1997. In: Final Program and Abstract Book of the Second International Symposium on Pneumococci and Pneumococcal Disease; March 19-23, 2000; Sun City, South Afriea. Abstract P-30.

69. Klein RS, Adachi N. An effective hospital-based pneumococcal immunization program. Arch Intern Med 1986;146:327-329.

70. Jackson LA, Benson P, Sneller VP, Butler JC. Thompson RS, Chen RT, et al. Safety of revaccination with pneumococcal polysaccharide vaccine. JAMA 1999;281:243-248.

\title{
OSHA's New Inspection Plan Targets Hospitals and Nursing Homes
}

Gina Pugliese, RN, MS

Martin S. Favero, PhD

Hospitals and nursing homes will join the ranks of other high-hazard work sites that are subject to wall-to-wall safety and health inspections by OSHA, based on the employers' response to an annual injury survey, according to an enforcement directive that went into effect September 8, 2000.

The agency announced that it will conduct some 4,200 site inspections over the next several months as part of its sitespecific enforcement program that was launched in 1996 when employers were first required to answer an OSHA injuryand-illness survey. Under the latest agency compliance directive, $00-05$ (CPL 2), OSHA will inspect mid- and largersized sites (those with 40 or more workers), focusing initially on those with a lost workday injury and illness rate of 14 cases per 100 or more workers.

The work sites targeted in the inspection plan were identified by OSHA earlier this year after it reviewed data collected in a 1998 survey of 80,000 employers. The agency identified 13,000 work sites, including 34 hospitals and 2,590 nursing and personal-care facilities, with high rates of lost workdays due to injury and illness.

OSHA sent letters to the 13,000 employers informing them of their work site's status. The letter encouraged employers to hire safety and health consultants or to use OSHA's on-site consultation program. OSHA plans to inspect 4,200 of the 13,000 workplaces that received letters.

FROM: www.osha-slc.gov/OshDoc/ Directive data/CPL_2_2000-5.html. Compliance directive 00-05(CPL2). 